\title{
Cytotoxicity Screening of Plants of Genus Piper in Breast Cancer Cell Lines
}

\author{
Somchai Sriwiriyajan ${ }^{1}$, Thippawan Ninpesh ${ }^{1}$, Yaowapa Sukpondma ${ }^{2}$, \\ Tapanawan Nasomyon ${ }^{1}$ and Potchanapond Graidist ${ }^{1,3 *}$ \\ ${ }^{1}$ Department of Biomedical Sciences, Faculty of Medicine, ${ }^{2}$ Department of Chemistry, Faculty of Science, ${ }^{3}$ The Excellent \\ Research Laboratory of Cancer Molecular Biology, Prince of Songkla University, Songkhla 90110, Thailand
}

*For correspondence: Email: gpotchan@medicine.psu.ac.th; Tel: +66 74451184; Fax: +66 74429584

\begin{abstract}
Purpose: To examine whether seven species of plants of genus Piper possess anti-cancer effects. Methods: One normal breast and three breast cancer cell lines were used to test cytotoxic effects over a period of 72 h using 3-(4,5-dimethylthiazol-2-yl)-2,5-diphenyltetrazolium bromide (MTT) assay. The dried plants were extracted with methanol and dichloromethane, and the effective extract isolated by crystallization, acid/base extraction and column chromatography techniques. Fragmented DNA was purified by phenol/chloroform/isoamyl alcohol.

Results: Methanol and dichloromethane extracts of Piper retrofractum, Piper betle, especially Piper nigrum, exhibited strong effect on MDA-MB-468. When the crude extract of $P$. nigrum was then separated by column chromatography, fraction D showed activity against both MCF-7 and MDA-MB-468 cells. Fraction $D E$ that was isolated from $D$ demonstrated a highly cytotoxic effect with $I C_{50}$ values of $8.33 \pm 1.27$ and $7.48 \pm 0.57 \mu \mathrm{g} / \mathrm{ml}$ on MCF-7 and MDA-MB-468 cells, respectively. Furthermore, fraction DF exhibited a strong cytotoxic effect only on MCF-7 with IC50 value of $6.51 \pm 0.39 \mu \mathrm{g} / \mathrm{ml}$. DNA smears of MCF-7 and MDA-MB-468 cells treated with fraction DE and DF were observed within 7 days.

Conclusions: These results indicate that the compounds isolated from $P$. nigrum, viz, $D E$ and $D F$, have cytotoxic effect on breast cancer cell lines. These fractions could be promising agent for breast cancer treatment. Further studies on the isolation, structural and mechanism elucidation of the active compound are still needed being carried out.
\end{abstract}

Keywords: Cytotoxicity, Breast cancer, P. nigrum, DNA fragmentation

Tropical Journal of Pharmaceutical Research is indexed by Science Citation Index (SciSearch), Scopus, International Pharmaceutical Abstract, Chemical Abstracts, Embase, Index Copernicus, EBSCO, African Index Medicus, JournalSeek, Journal Citation Reports/Science Edition, Directory of Open Access Journals (DOAJ), African Journal Online, Bioline International, Open-J-Gate and Pharmacy Abstracts

\section{INTRODUCTION}

Breast cancer is a major cause of death in the female population. According to worldwide data in 2008 of American Cancer Society, there are $1,383,500$ new cancer cases $(23 \%)$ and 458,400 cancer deaths $(14 \%)$ [1]. The most common treatment for breast cancer is radiotherapy, hormonal therapy and chemotherapy. The patients often experience many extreme side effects from anti-cancer drugs. Intensive treatment with radiotherapy or chemotherapy is usually associated with adverse side effects ranging from nausea to bone marrow failure [2]. Moreover, tumor cells are usually resistant to chemotherapy [3]. Therefore, phytochemicals from medicinal plants may be an option for treatment.

Numerous studies have reported that phytochemicals isolated from plants of the Piper genus are potent biological agents with 
anticancer properties [4-7]. The major phytochemical components of this genus are alkaloids, for instance, piperine, piperolein and piperlonguminine [8]. Piperine suppresses the expression and secretion of MMP 9, decreases activation of NF-KB and AP-1 leading to inhibition of invasion and metastasis of HT-180 cell [9]. Pellitorine has cytotoxic effect on human promyelocytic leukemia cells (HL60) with $I_{50}$ value of $43.86 \mu \mathrm{M}$. Piperidine at a concentration of $58.72 \mu \mathrm{M}$ inhibits growth of human epithiloma cells of laryax (HEp2) by $51.38 \%$ [4]. Dehydropipernolanine, piperloein $B$ and pipernonaline have inhibitory effect on HepG2 cell with $\mathrm{IC}_{50}$ value of $4.84,3.04$ and $5.23 \mu \mathrm{M}$, respectively [10]. Although the cytotoxic effect of pepper compounds was studied on many cancer cell lines, it has not been reported in breast cancer cell lines. In this study, we focused on the cytotoxic effect of plants of the Piper genus on three breast cancer and one normal breast cancer cell lines.

\section{EXPERIMENTAL}

\section{Plant materials}

The parts of plants were collected in March from Songkhla and Nonthaburi provinces in Thailand. All of the plant specimens were identified by Assistant Professor Dr. Supreeya Yuenyongsawad and deposited in the herbarium at the Southern Centre of Thai Traditional Medicine, Department of Pharmacognosy and Pharmaceutical Botany, Prince of Songkla University, Thailand. Table 1 summarizes the information related to the species that were used in this study.

\section{Crude extraction}

The dried parts of all plants were cut into small sizes. Fifty grams of each sample were extracted three times with $150 \mathrm{ml}$ of methanol or dichloromethane for $72 \mathrm{~h}$ at room temperature. Solvent-containing extracts were pooled, filtered using Whatman filter paper (No.1) and then concentrated in vacuum below $45{ }^{\circ} \mathrm{C}$ using a rotary evaporator.

Table 1: Plant species investigated

\begin{tabular}{llll}
\hline Plant & Family & Part of plant & Voucher specimens no. \\
\hline Piper nigrum L. & Piperaceae & Fruit & SKP 146161401 \\
Piper retrofractum Vahl & Piperaceae & Fruit & SKP 146161801 \\
Piper ribesoides Wall. & Piperaceae & Stem & SKP 146161802 \\
Piper betle L. & Piperaceae & Leaf & SKP 146160201 \\
Piper samentosum Roxb. Ex Hunt. & Piperaceae & Leaf & SKP 146161901 \\
Piper cubeba L. & Piperaceae & Fruit & SKP 146160302 \\
Piper porphyrophyllum N.E.Br. & Piperaceae & Leaf & SKP 146161601 \\
\hline
\end{tabular}

\section{Extraction procedure}

Five hundred grams of $P$. nigrum powder were isolated into a brown pellet (P1) via crystallization according to Reshmi et al [4]. Briefly, the powder of $P$. nigrum was mixed into dichloromethane with 1:1.2 volumetric mixing ratio. Then, the mixture was incubated in a shaking incubator at $35{ }^{\circ} \mathrm{C}$ for $2 \mathrm{~h}$. The extract was filtered and evaporated on a rotary evaporator. One hundred milliliters of cold diethyl ether was added into the residue and shook for $5 \mathrm{~min}$ after the residue was cooled in an ice bath. The mixture was evaporated and cooled again. In recrystallization step, the cold diethyl ether was added and the mixture was shook for $25 \mathrm{~min}$. Then, the yellow crystal (P2) was separated by filtration through filter paper. And the solvent was evaporated on a rotary evaporator to obtain extract CP2, which was divided into two groups. The first group was extracted using acid/base extraction (10 \% hydrochloric acids and saturated sodium hydroxide) to obtain two parts, P3 and CP3. Then, the second group of CP2 was purified by column chromatography using a silica gel plate (Merck Kiesegel 60) with $100 \%$ dichloromethane and dichloromethane/methanol (9:1) was used as an eluting solvents. Eleven fractions (A-K) were collected according to TLC spots. The active fraction $D$ was then processed by column chromatography and eluted with ethyl acetate/hexane (2:3). Finally, the fractions DE and DF were obtained and tested on cancer cell lines.

\section{Thin layer chromatography (TLC) analysis}

The samples of each $P$. nigrum fraction were submitted to TLC plates (a silica coated plate, Merck). For fractions $A$ to $\mathrm{K}$, the bands were separated using $100 \%$ dichloromethane as mobile phase. Fractions $\mathrm{F}$ to $\mathrm{K}$ were eluted again with $5 \%$ methanol in dichloromethane to observe their chromatogram legibly. The obtained chromatogram was revealed with Dragendroff's reagent. The fractions containing alkaloids were indicated by the presence of an orange band [11]. The TLC-patterns were used to select the fractions for testing cytotoxicity. 


\section{Cell culture conditions}

MCF-7, MDA-MB-231, MDA-MB-468 and MCF$12 \mathrm{~A}$ cells were obtained from ATCC (Manassas, VA, USA). MCF-7 cells were grown in RPMI 1640 (Invitrogen) containing $10 \%$ fetal bovine serum (Invitrogen) with 50 units $/ \mathrm{ml}$ of penicillin (Invitrogen) and $50 \mu \mathrm{g} / \mathrm{ml}$ of streptomycin (Invitrogen). MDA-MB-231 and MDA-MB-468 cells were grown in DMEM (Invitrogen) supplemented with 50 units/ml of penicillin (Invitrogen) and $100 \mu \mathrm{g} / \mathrm{ml}$ of streptomycin (Invitrogen). MCF-12A cells were grown in a 1:1 mixture of DMEM and Ham's F12 medium (PAA Laboratories $\mathrm{GmbH}$ ) containing $5 \%$ horse serum (Invitrogen) with $20 \mathrm{ng} / \mathrm{ml}$ human epidermal growth factor (Invitrogen), $100 \mathrm{ng} / \mathrm{ml}$ cholera toxin (Sigma), $0.01 \mathrm{mg} / \mathrm{ml}$ bovine insulin (Sigma) and $500 \mathrm{ng} / \mathrm{ml}$ hydrocortisone, $95 \%$ (Sigma). All cells were maintained in a humidified incubator at $37{ }^{\circ} \mathrm{C}$ and $5 \% \mathrm{CO}_{2}$.

\section{Cytotoxic assay}

MCF-7, MDA-MB-231, MDA-MB-468 and MCF$12 \mathrm{~A}$ cells were seeded in 96 -well plates at a density of $2 \times 10^{4}$ cells/well. The cell lines were exposed to crude extracts in a concentration range of $0-80 \mu \mathrm{g} / \mathrm{ml}$ and piperine in a concentration range of $1.25-20 \mu \mathrm{g} / \mathrm{ml}$ for $72 \mathrm{~h}$. Then the cells were washed with $1 \mathrm{X}$ PBS and incubated in $100 \mu \mathrm{l}$ of $0.5 \mathrm{mg} / \mathrm{ml}$ MTT at $37{ }^{\circ} \mathrm{C}$ for $30 \mathrm{~min}$. Under light protection, the dark blue crystals of formazan (MTT metabolites) were dissolved with $100 \mu \mathrm{l}$ DMSO and incubate at 37 ${ }^{\circ} \mathrm{C}$ for $30 \mathrm{~min}$. Absorbance was measured at 570 and $650 \mathrm{~nm}$ using a microplate reader spectrophotometer. Viable cells were represented as a percentage of survival and calculated as in Eq $1(n=3)$.

Survival $(\%)=\left\{\left(\mathrm{As}_{570}-\mathrm{As}_{650}\right) /\left(\mathrm{Ac}_{570}-\mathrm{Ac}_{650}\right)\right\} 100 .$.

where $\mathrm{As}_{570}, \mathrm{As}_{650}, \mathrm{Ac}_{570}$, and $\mathrm{Ac}_{650}$ are the absorbance of the test samples (at 570 and 650 $\mathrm{nm}$ ) and negative control (at 570 and $650 \mathrm{~nm}$ ), respectively.

According to US $\mathrm{NCl}$ plant screening program, a crude extract is generally considered to have in vitro cytotoxic activity with $\mathrm{IC}_{50}$ value $\leq 20 \mu \mathrm{g} / \mathrm{ml}$, while this value was deemed at $\leq 4 \mu \mathrm{g} / \mathrm{ml}$ for a pure compound [12].

\section{DNA fragmentation}

The cells were treated with the crude extracts and positive controls, doxorubicin and curcumin. The treated cells were incubated up to 7 days and collected everyday by trypsinization and centrifugation. The DNA was extracted with phenol/chloroform/isoamyl alcohol and precipitated with 2:3 volume of isopropanol. The precipitated DNA was washed once with $70 \%$ ethanol (v/v) and air-dried for $30 \mathrm{~min}$. DNA was loaded onto a $1.5 \%$ agarose gel and visualized with ethidium bromide under UV light.

\section{Statistical analysis}

Median inhibition concentration $\left(\mathrm{IC}_{50}\right)$ was obtained by SoftMax $®$ Pro 5 program (MDS Analytical Technologies Inc., California, USA) and expressed as the mean \pm standard deviation.

\section{RESULTS}

\section{Cytotoxic effect of crude extracts on breast cancer cells}

Three breast cancer (MCF-7, MDA-MB-231, MDA-MB-468) and one normal breast (MCF12A) cell lines were used to test the cytotoxic effect of seven Piper genus plants at $72 \mathrm{~h}$. The cytotoxicity of the crude extracts of Piper plants is shown in Table 2. Regarding the methanolic crude extracts, $P$. nigrum and $P$. retrofractum revealed high effect on MDA-MB-468 cells with $\mathrm{IC}_{50}$ value of $9.04 \pm 0.71 \mu \mathrm{g} / \mathrm{ml}$ and $12.27 \pm 2.14$ $\mu \mathrm{g} / \mathrm{ml}$, respectively. However, $P$. ribesoides, $P$. betle and $P$. cubeba exhibited a lower cytotoxic effect on breast cancer cell lines. Concerning dichloromethane extracts, $P$. nigrum and $P$. betle demonstrated strong effect on MDA-MB-468 cells with $\mathrm{IC}_{50}$ value of $7.94 \pm 4.52 \mu \mathrm{g} / \mathrm{ml}$ and $11.26 \pm 0.01 \mu \mathrm{g} / \mathrm{ml}$, respectively. Moreover, $P$. betle showed cytotoxic on MDA-MB-231 cells with $I_{50}$ value of $19.76 \pm 2.87 \mu \mathrm{g} / \mathrm{ml}$. Both methanol and dichloromethane crude extracts of all tested plants exhibited low-level effect on MCF-12A cells. Our results indicated that $P$. nigrum possessed strong cytotoxic activity on breast cancer cell lines.

\section{Cytotoxic effect of extracts of $P$. nigrum}

Since $P$. nigrum represented strong cytotoxic activity on breast cancer cell lines, here we performed MTT assay to test whether the cytotoxic effect of crude extract of $P$. nigrum come from two pure compounds (piperine and pellitorine) or other compounds. Commercial piperine and pellitorine, major compound of $P$. nigrum, were used to test their cytotoxic effects and compared them with those curcumin, the active compound from turmeric, the cytotoxic effects of which on many cancer cells have been reported [7-9]. Our results revealed that both piperine and pellitorine had less effect than crude 
Table 2: Cytotoxicity of dichloromethane and methanol crude extracts of Piper on breast cancer and normal breast cell lines

\begin{tabular}{|c|c|c|c|c|}
\hline \multirow{2}{*}{ Plant } & \multicolumn{4}{|c|}{$\mathrm{IC}_{50}$ value $\pm \mathrm{SD}(\mu \mathrm{g} / \mathrm{mI})^{\mathrm{a}}$} \\
\hline & MCF-7 & MDA-MB-468 & MDA-MB-231 & MCF-12A \\
\hline \multicolumn{5}{|l|}{ Methanol crude extract } \\
\hline$P$. nigrum $L$. & $20.25 \pm 0.01$ & $9.04 \pm 0.71^{\mathrm{b}}$ & $22.37 \pm 2.31$ & $46.31 \pm 0.76$ \\
\hline$P$. retrofractum Vahl & $19.69 \pm 0.88^{b}$ & $12.27 \pm 2.14^{b}$ & $17.10 \pm 0.46^{b}$ & $32.41 \pm 5.94$ \\
\hline P. ribesoides Wall. & $32.27 \pm 0.46$ & $25.24 \pm 0.27$ & $>80$ & $>80$ \\
\hline P. betle L. & $19.30 \pm 1.03^{b}$ & $20.83 \pm 3.02$ & $38.25 \pm 2.61$ & $>80$ \\
\hline P. sarmentosum Roxb. & $>80$ & $>80$ & $>80$ & $>80$ \\
\hline P. cubeba L. & $26.63 \pm 0.47$ & $22.95 \pm 2.09$ & $59.19 \pm 3.97$ & $>80$ \\
\hline P. porphyrophyllum N.E.Br. & $>80$ & $>80$ & $>80$ & $>80$ \\
\hline \multicolumn{5}{|c|}{ Dichloromethane crude extract } \\
\hline$P$. nigrum $L$. & $23.46 \pm 1.10$ & $7.94 \pm 4.52^{b}$ & $38.82 \pm 0.23$ & $35.65 \pm 0.27$ \\
\hline P. retrofractum Vahl & $20.03 \pm 2.85$ & $17.34 \pm 4.08^{b}$ & $21.77 \pm 2.32$ & $>80$ \\
\hline P. ribesoides Wall. & $>80$ & $28.91 \pm 3.17$ & $23.40 \pm 2.26$ & $>80$ \\
\hline$P$. betle $\mathrm{L}$. & $34.33 \pm 1.25$ & $11.26 \pm 0.01^{b}$ & $19.76 \pm 2.87^{b}$ & $>80$ \\
\hline P. sarmentosum Roxb. & $>80$ & $>80$ & $>80$ & $>80$ \\
\hline P. cubeba L. & $64.41 \pm 1.61$ & $40.82 \pm 0.33$ & $32.98 \pm 1.01$ & $>80$ \\
\hline P. porphyrophyllum N.E.Br. & $>80$ & $38.82 \pm 0.23$ & $>80$ & $>80$ \\
\hline
\end{tabular}

${ }^{a} n=3 ;{ }^{b} / C_{50}$ is $<20 \mu \mathrm{g} / \mathrm{ml}$, considered highly cytotoxic against to each cell line

Table 3: Cytotoxicity of from P. nigrum on breast cancer and normal breast cell lines

\begin{tabular}{|c|c|c|c|c|}
\hline \multirow{2}{*}{ Compound } & \multicolumn{4}{|c|}{$\mathrm{IC}_{50}$ value $\pm \mathrm{SD}(\mu \mathrm{g} / \mathrm{ml})^{\mathrm{a}}$} \\
\hline & MCF-7 & MDA-MB-468 & MDA-MB-231 & MCF-12A \\
\hline P1 & $>80$ & $>80$ & $>80$ & $>80$ \\
\hline $\mathrm{P} 2$ & $>80$ & $20.10 \pm 3.83$ & $53.62 \pm 1.44$ & $>80$ \\
\hline P3 & $61.35 \pm 3.01$ & $40.91 \pm 6.22$ & $>80$ & $>80$ \\
\hline $\mathrm{CP} 2$ & $7.45 \pm 1.59^{c}$ & $18.19 \pm 0.59^{c}$ & $21.68 \pm 1.69$ & $48.07 \pm 0.46$ \\
\hline CP3 & $17.74 \pm 1.26^{c}$ & $9.32 \pm 3.65^{c}$ & $25.88 \pm 0.61$ & $45.86 \pm 5.20$ \\
\hline Piperine $^{b}$ & $>20$ & $19.07 \pm 0.84$ & $>20$ & $>20$ \\
\hline Pellitorine $^{b}$ & $>20$ & $>20$ & $>20$ & $>20$ \\
\hline Curcumin $^{\mathrm{b}}$ & $15.40 \pm 4.26$ & $3.91 \pm 1.43^{d}$ & $8.92 \pm 1.84$ & $4.23 \pm 1.11$ \\
\hline \multicolumn{5}{|c|}{$1^{\text {st }}$ column chromatography } \\
\hline C & $23.12 \pm 2.29$ & $16.79 \pm 4.42^{\mathrm{C}}$ & $44.02 \pm 3.18$ & $39.38 \pm 0.70$ \\
\hline$D$ & $5.82 \pm 0.15^{c}$ & $7.34 \pm 0.51^{c}$ & $24.39 \pm 1.18$ & $36.13 \pm 6.67$ \\
\hline $\mathrm{F}$ & $18.79 \pm 1.09^{c}$ & $21.75 \pm 1.45$ & $27.39 \pm 2.66$ & $34.46 \pm 1.56$ \\
\hline G & $65.17 \pm 3.45$ & $>80$ & $>80$ & $>80$ \\
\hline I & $48.17 \pm 3.83$ & $70.68 \pm 6.25$ & $>80$ & $>80$ \\
\hline \multicolumn{5}{|c|}{$2^{\text {nd }}$ column chromatography } \\
\hline DB & $14.62 \pm 0.53^{\mathrm{c}}$ & $24.29 \pm 3.74$ & $23.61 \pm 1.20$ & $>80$ \\
\hline DC & $23.09 \pm 0.26$ & $12.62 \pm 3.31^{\mathrm{C}}$ & $28.83 \pm 5.26$ & $74.33 \pm 2.45$ \\
\hline DD & $14.73 \pm 1.41^{\mathrm{c}}$ & $25.22 \pm 1.98$ & $23.39 \pm 4.64$ & $21.95 \pm 4.30$ \\
\hline $\mathrm{DE}$ & $8.33 \pm 1.27^{c}$ & $7.48 \pm 0.57^{\mathrm{c}}$ & $20.29 \pm 1.37$ & $6.91 \pm 0.01^{c}$ \\
\hline DF & $6.51 \pm 0.39^{c}$ & $22.52 \pm 1.07$ & $33.02 \pm 2.58$ & $20.66 \pm 2.80$ \\
\hline DG & $29.52 \pm 1.92$ & $14.33 \pm 3.56^{\mathrm{c}}$ & $30.80 \pm 5.12$ & $34.13 \pm 1.72$ \\
\hline $\mathrm{DH}$ & $22.05 \pm 1.09$ & $17.74 \pm 1.22^{\mathrm{c}}$ & $26.87 \pm 2.05$ & $>80$ \\
\hline
\end{tabular}

${ }^{a}$ Values are obtained from three independent experiments. ${ }^{D}$ Piperine, pellitorine and curcumin were standard powder used to test cytotoxic effect with maximum concentration $20 \mu \mathrm{g} / \mathrm{ml}$. ${ }^{c}$ The $I C_{50}$ is $<20 \mu \mathrm{g} / \mathrm{ml}$, considered highly cytotoxic against to each cell line. ${ }^{d}$ The $I C_{50}$ is $<4 \mu \mathrm{g} / \mathrm{ml}$, considered highly cytotoxic against to each cell line. 
extract of $P$. nigrum on MDA-MB-468 cells. Moreover, curcumin showed strong effect on cancerous cell lines (MDA-MB-231 and MDAMB-468) and also normal breast cell line (MCF12A) (Table 3).

The compounds of $P$. nigrum were separated by crystallization and all the extracts were tested for cytotoxic activity. The finding suggested that the crude extract from crystallization, namely P1, did not effect to all cell lines, while the crude extract from recrystallization, namely $P 2$, exhibited cytotoxic activity on MDA-MB-468 cells with $\mathrm{IC}_{50}$ value of $20.10 \pm 3.83 \mu \mathrm{g} / \mathrm{ml}$; which is most likely piperine. In addition, the $1 \mathrm{H}-\mathrm{NMR}$ profile of $\mathrm{P} 2$ was similar to that of commercial piperine (data not shown).

The supernatant from the recrystallization step was evaporated to obtain the crude extract, CP2. The CP2 was toxic to MCF-7 cells with $I_{50}$ value of $7.45 \pm 1.59 \mu \mathrm{g} / \mathrm{ml}$. This crude extract was divided into two groups. The first group was processed by acid/base extraction to give two parts, P3 and CP3. CP3 killed MDA-MB-468 cells with $\mathrm{IC}_{50}$ value of $9.32 \pm 3.65 \mu \mathrm{g} / \mathrm{ml}$, whereas $\mathrm{P3}$ had little or no effect on MDA-MB-468 and MCF7 cells. The $\mathrm{IC}_{50}$ values of all the extracts are shown in Table 3 . The second group (without piperine) was then isolated by column chromatography to give eleven fractions (A to K).

Five fractions (C, D, F, G, and I) from eleven fractions (A to $K$ ) separated by TLC were selected to test for cytotoxic activity on breast cancer cell lines. Fraction $D$ had the best cytotoxic effect on three breast cancer cell lines; MCF-7 and MDA-MB-468 cells, with $\mathrm{IC}_{50}$ values of $5.82 \pm 0.15 \mu \mathrm{g} / \mathrm{ml}$ and $7.34 \pm 0.51 \mu \mathrm{g} / \mathrm{ml}$, respectively. The $\mathrm{IC}_{50}$ values of the five fractions are shown in Table 3. All the fractions were visualized for alkaloids by the Dragendoeff's reagent. Fractions $D, E$ and $F$ were observed as orange spots on the TLC plate (data not shown). The results showed that fractions $D, E$ and $F$ were alkaloids. Then, the fraction $D$ was subjected to column chromatography on silica gel. Seven fractions (DB, DC, DD, DE, DF, DG and $\mathrm{DH}$ ) from 9 fractions (DA to $\mathrm{DI}$ ) were selected using TLC. A high-level reduction in MCF-7 cell survival was observed when they were treated with fractions $\mathrm{DE}$ and $\mathrm{DF}\left(\mathrm{IC}_{50}\right.$ value at $8.33 \pm 1.27 \mu \mathrm{g} / \mathrm{ml}$ and $6.51 \pm 0.39$ $\mu \mathrm{g} / \mathrm{ml})$. In addition, fraction DE exhibited a strong cytotoxic effect on MDA-MB-468 and MCF-12A cells (Table 3 ). These results indicated that fractions DE and DF were highly effective against breast cancer cell lines.

\section{P. nigrum fractions induced DNA fragmentation in breast cancer cells}

DNA fragmentation assay was used to determine that the cytotoxic effect of fractions DE and DF induced cell death through apoptosis. From the cytotoxic results, it was apparent that fraction DE was strongly effective against MDA-MB-468 and MCF-7 cells, while fraction DF was toxic only on MCF-7 cells. MDA-MB-468 and MCF-7 cells were, subsequently, incubated with fraction DE and DF at their representative $I_{50}$ concentrations for 7 days. Doxorubicin (a chemotherapic agent) and curcumin, a known apoptotic inducer, were used in this study as positive controls. DNA smear was observed on MDA-MB-468 cells at 2-7 days after treatment with doxorubicin, curcumin and fraction DE (Figure 1Aa-1Ac). The results revealed that fraction $D E$ may induce cell death through apoptosis similar to the way doxorubicin and curcumin do. Regarding MCF-7 cells, among the cells treated with doxorubicin, curcumin, fraction DE and DF, DNA smear was observed at 7 days (Figure 1Ba-1Bd). Fraction DE and DF were able to induce DNA fragmentation on MCF-7 more than doxorubicin and curcumin. These results suggest that the cytotoxicity observed upon treatment with fraction DE and DF was through apoptosis.

\section{DISCUSSION}

There are several reports which show that extracts from plants of genus Piper exhibit cytotoxic activity. Hot ethyl acetate and cold hexane:water extracts of $P$. longum showed a dose dependent cytotoxic effect on leukemic cell lines [13]. The methanolic extracts of $P$. longum was found to be cytotoxic for Dalton's lymphoma ascites (DLA) and Ehrlich ascites carcinoma (EAC) cells with $\mathrm{IC}_{50}$ value of $250 \mu \mathrm{g} / \mathrm{ml}$ and 100 $\mu \mathrm{g} / \mathrm{ml}$, respectively [7]. In addition, methanol extract of Piper crocatum Ruiz and Pav was a cytotoxic to on breast cancer (T47D) cells with $I_{50}$ value of $44.25 \mu \mathrm{g} / \mathrm{ml}$ [5]. Three amides from $P$. sarmentosum Roxb showed a cytotoxic effect on humam breast cancer (MCF-7 and MDA-MB231), human ovarian carcinoma (SKOV3) and human colon/intestinal carcinoma cell lines at concentration of $20 \mu \mathrm{g} / \mathrm{ml}$ with percentage of cell survival $>50 \%$ [14].

Our first aim of this study was to determine the cytotoxic activity of the methanol and dichloromethane extracts of the Piper plant Methanol extracts of $P$. retrofractum and $P$. nigrum were found to be highly active against MDA-MB-468 cells. For dichloromethane 
A: MDA-MB-468 Doxorubicin

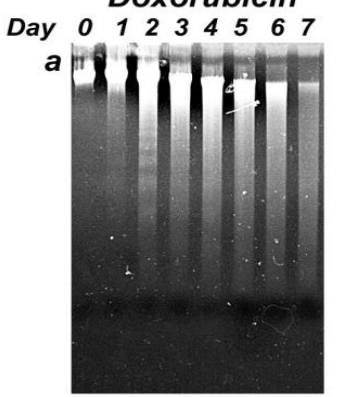

Curcumin

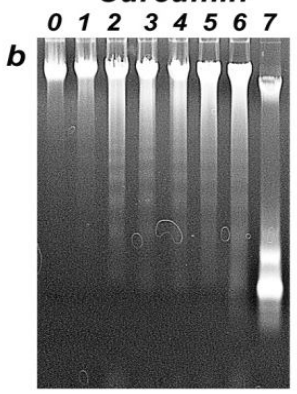

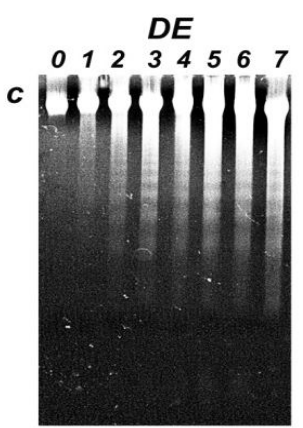

B: MCF-7

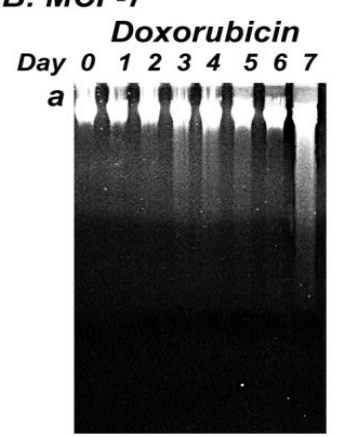

Curcumin 012344567 ourtert
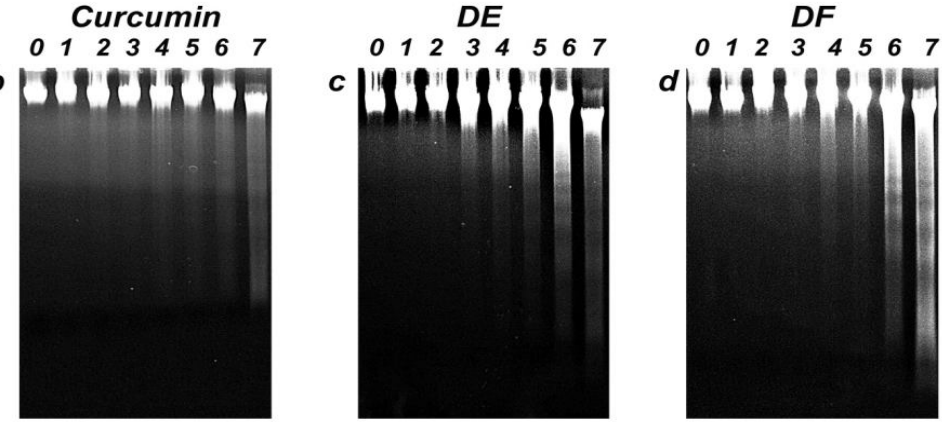

Figure 1: DNA fragmentation induced by crude extracts from $P$. nigrum. Cells were treated with fractions DE and $\mathrm{DF}$ and incubated for 7 days at their respective $\mathrm{IC}_{50}$ concentrations. DNA fragmentation was then assessed by agarose gel electrophoresis and ethidium bromide staining. Doxorubicin and curcumin were used as positive controls. MDA-MB-468 cells were treated with (Aa) $0.23 \mu \mathrm{M}$ doxorubicin, (Ab) $10.86 \mu \mathrm{M}$ curcumin and (Ac) 7.48 $\mu \mathrm{g} / \mathrm{ml} \mathrm{DE}$. MCF-7 cells were treated with (Ba) $0.78 \mu \mathrm{M}$ doxorubicin, (Bb) $41.80 \mu \mathrm{M}$ curcumin, (Bc) $8.33 \mu \mathrm{g} / \mathrm{ml} \mathrm{DE}$ and $(\mathrm{Bd}) 6.51 \mu \mathrm{g} / \mathrm{ml} \mathrm{DF}$. The data are representative of three independent experiments

extracts, $P$. betle and $P$. nigrum had strong cytotoxic effects on MDA-MB-468 cells. The dichloromethane extract of $P$. nigrum exhibited highly cytotoxic effects with $\mathrm{IC}_{50}$ value of $7.94 \pm$ $4.52 \mu \mathrm{g} / \mathrm{ml}$. Consequently, it was chosen for further isolation of the cytotoxic compound with column chromatography.

Piperine is a major pungent alkaloids present in Piper plant such as $P$. nigrum. It has been reported to show cytotoxic activity towards cancer cell lines at high concentrations $[6,7,14]$. Piperine exerted cytotoxic activity against human leukemia (CEM and HL-60), murine melanoma (B16) and human colon (HCT-8) cell lines at concentration equal or higher than $17 \mu \mathrm{g} / \mathrm{ml}$ [6]. Similarly, our study produced results which corroborate the findings in previous studies. Piperine extracted from $P$. nigrum had less effect on breast cancer cell lines with $\mathrm{IC}_{50}$ of $19 \mu \mathrm{g} / \mathrm{ml}$. Therefore, we decided to eliminate piperine from the crude extracts using crystallization technique. After crystallization, crude extract P1 and supernatant were obtained. The $I C_{50}$ value and ${ }^{1} \mathrm{H}$-NMR profile of $\mathrm{P} 1$ showed that this extract was piperine. Therefore, CP2 that separated later should not contain piperine. Then, CP2 was further separated by column chromatography to get eleven fractions ( $A$ to $K$ ). The effective fractions (DE and DF) which were isolated from fraction $D$ were alkaloid. Alkaloids often possess potent cytotoxicity to many cells, which make them interesting in terms of having potential anticancer properties. Thirty-eight natural pure compounds have been found in genus Piper; the major ones are alkaloids, terpenes and polyphenols [8]. The pepper alkaloids, piperine and piplartine, exhibited cytotoxic effects on HL60 , CEM, HCT-8 and B-16 cells [6].

In this present study, we used three breast cancer cell lines that have different characteristics. MCF-7 cell contains the p53 wildtype, while MDA-MB-468 and MDA-MB-231 cells represent p53 mutations. The results showed that fractions DE and DF had a higher cytotoxic effect on MCF-7 and MDA-MB-468 than MDAMB-231 cells. In MDA-MB-468 cells, the p53 mutation occurred at codon 273 (Arg to His) [15], whereas the p53 mutation of MDA-MB-231 cells is found at codon 280 (Arg to Lys). The mutant p53 of MDA-MB-231 cells stabilized MDM2, the negative regulator of $p 53$ hence these cells were protected from apoptosis [16]. Therefore, 
fractions $D E$ and DF may induce apoptosis in MCF7, MDA-MB-468 and MDA-MB-231 cells through different pathways.

Numerous studies of alkaloids isolated from plants have been reported including berberine, camptothecin and ellipticin. Berberine alkaloid isolated from Chinese herbs, induced apoptosis in MDM2-overexpressing cells. Down regulation of MDM2 by berberine occurs at a posttranscriptional level through modulation of death domain-associated protein followed by MDM2 self-ubiquitination and degradation [17]. The alkaloid used as antitumor drug, camptothecin, induce apoptosis which bind simultaneously both to the DNA and topoisomerase I and stabilizes the cleavage complex formed. This collision of cleavage complex with replication forks induces double-strand breaks that lead to apoptosis [18]. This alkaloid up regulates p21WAF1/CIP1 and induces apoptosis in breast cancer cell line in both p53-dependent (MCF-7) and -independent (MDA-MB-468) pathways [19]. Moreover, ellipticine (5,11-dimethyl-6H-pyrido[4,3b]carbazole), a cytotoxic plant alkaloid, is isolated from Ochrosia elliptica Labill. This compound is known to inhibit topoisomerase II and induces apoptosis by increasing the expression of p53 and KIP1/P27 that lead to Fas/APO-1 and Bax that accumulate in treated MCF-7 cells. In addition, ellipticine also increases Fas ligands (mFasL and sFasL) that cause the enhancing of Fas/APO-1 levels and caspase-8 activity, and increase the expression of Bax and decrease the expression of $\mathrm{Bcl}-2$ and $\mathrm{Bcl}-\mathrm{XL}$ leading to cytochrome $c$ release from mitochondria, which activates caspase-9 [20].

\section{CONCLUSION}

The results suggest that $P$. retrofractum, $P$. betle and $P$. nigrum extracts have cytotoxic effect on breast cancer cell lines. The methanol and dichloromethane crude extracts of $P$. nigrum possess strong cytotoxic activity. In addition, fractions DE and DF from $P$. nigrum exhibit the highest cytotoxic activity on breast cancer cell lines. Both fractions also promoted DNA fragmentation which is related to the induction of cell death through apoptosis. However, the target molecules of the extracts are not known. Therefore, further studies should involve the isolation of the active agent(s) of $P$. nigrum as well as the investigation of the molecular mechanism of action of the compound(s) in human breast cancer cell lines.

\section{ACKNOWLEDGEMENT}

This work was financially supported via a research grants from the Graduate School, Faculty of Medicine (no. 55-326-04-2-3) and PSU Research Fund (no. MED550127S), Prince of Songkla University, Hat Yai, Songkhla, Thailand.

\section{REFERENCES}

1. Ferlay J, Shin HR, Bray F, Forman D, Mathers C, Parkin DM. Estimates of worldwide burden of cancer in 2008: GLOBOCAN 2008. Int J Cancer 2010; 127: 2893-2917.

2. Cancer Research UK [internet]. London: Cancer Research UK; 2011 Available at http://cancerhelp.cancerresearchuk.org/aboutcancer/ treatment/cancer-drugs/side-effects/. Accessed February 14, 2013.

3. Raguz S, Yague E. Resistance to chemotherapy: new treatments and novel insights into an old problem. $\mathrm{Br}$ J Cancer 2008; 99: 387-391.

4. Reshmi SK, Sathya E, Devi PS. Isolation of piperdine from Piper nigrum and its antiproliferative activity. Afr J Pharm Pharmacol 2010; 4: 562-573.

5. Wicaksono BD, Handoko YA, Arung ET, Kusuma IW, Yulia D, Pancaputra AN, Sandra F. Antiproliferative effect of the methanol extract of Piper crocatum Ruiz \& Pav leaves on human breast (T47D) cells in-vitro. Trop J Pharm Res 2009; 8: 345-352.

6. Bezerra DP, Pessoa $C$, de Moraes MO, Silveira ER, Lima MA, Elmiro FJ, Costa-Lotufo LV. Antiproliferative effects of two amides, piperine and piplartine, from Piper species. Z. Naturforsch C 2005; 60: 539-543.

7. Sunila ES, Kuttan G. Immunomodulatory and antitumor activity of Piper longum Linn. and piperine. $J$ Etanopharmacol 2004; 90: 339-346.

8. Virinder SP, Subhash CJ, Gupta S, Sangeeta T, Vivek KR, Rajesh K, Azim A, Malhotra S, Kumar N, Jain R, et al. Polyphenols and alkaloids from piper species. Phytochemistry 1998; 49: 1069-1078.

9. Hwang YP, Yun HJ, Kim HG, Han EH, Chung YC, Jeong HG. Suppression of phorbol-12-myristate-13-acetateinduced tumor cell invasion by piperine via the inhibition of PKC/ERK1/2-dependent matrix metalloproteinase-9 expression. Toxicol Lett 2011; 203: 9-19.

10. Lee SW, Kim MS, Park MH, Park S, Lee WS, Chang JS, Rho M. Alkamides from Piper longum and Piper nigrum as Inhibitors of IL-6 action. Bull Korean Chem Soc 2010; 31: 921-924.

11. Sherma J, in: Zweig G, Sherma J (Eds.), Handbook of Chromatography, Vol. II, Cleveland, OH: CRC Press; 1972.

12. Geran RI, Greenberg NH, McDonald MM, Scumaker AM, Abbot BJ. Protocol for screening chemical agents and 
natural products against animal tumours and other biological systems. Cancer Chemotherapy Reports 1972; 3: 1-61.

13. Joy B, Sandhya $C P$, Remitha KR. Comparison bioevaluation of Piper longum fruit extracts. $J$ Chem Pharm Res 2010; 2: 612-622.

14. Atiax E, Ahmad F, Sirat HM, Arbain D. Antibacterial activity and cytotoxicity screening of Sumatran kaduk (Piper sarmentosum Roxb.). IJPT 2011; 10: 1-5.

15. Lacroix M, Toillon RA, Leclercq G. p53 and breast cancer, an update. Endocr Relat Cancer 2006; 13: 293-325.

16. Peng $Y$, Chen L, Li C, Lu W, Agrawal S, Chen J. Stabilization of the MDM2 oncoprotein by mutant $p 53$. J Biol Chem 2001; 276: 6874-6878.

17. Zhang X, Gu L, Li J, Shah N, He J, Yang L, Hu Q, Zhou $M$. Degradation of MDM2 by the interaction between berberine and DAXX leads to potent apoptosis in MDM2-overexpressing cancer cells. Cancer Res 2010; 70: 9895-9904.

18. Pommier Y. Topoisomerase I inhibitors: camptothecins and beyond. Nat Rev Cancer 2006; 6: 789-802.

19. Liu W, Zhang R. Upregulation of p21WAF1/CIP1 in human breast cancer cell lines MCF-7 and MDA-MB468 undergoing apoptosis induced by natural product anticancer drugs 10-hydroxycamptothecin and camptothecin through p53-dependent and independent pathways. Int J Oncol 1998; 12: 7931597.

20. Kuo PL, Hsu YL, Chang CH, Lin CC. The mechanism of ellipticine-induced apoptosis and cell cycle arrest in human breast MCF-7 cancer cells. Cancer Lett 2005; 223: 293-301. 